PROCEDIA

Studi Kasus dan Intervensi Psikologi

ISSN:2302-1462; e-ISSN: 2722-7669

Volume 8(4) 145-152, Desember 2020

DOI: $10.22219 /$ procedia.v8i4.14785

\title{
Terapi Disensitisasi Sistematis untuk menurunkan ketakutan pada anak dengan fobia telur asin
}

\author{
Jainal Ilmi, Universitas Muhammadiyah Malang, Malang, Indonesia
}

Korespondonesi:

Jainal Ilmi, email: jainalilmi1@gmail.com

\begin{abstract}
Riwayat artike
Naskah diterima:

$23 / 10 / 2020$

Revisi diterima:

$10 / 11 / 2020$

Naskah disetujui: $01 / 12 / 2020$
\end{abstract}

\begin{abstract}
Abstrak
Fobia spesifik adalah salah satu gangguan psikologis yang dapat menimbulkan kondisi stress yang besar saat berhadapan atau harus melakukan sesuatu yang berkaitan dengan stimulus fobianya. Subjek dalam kasus ini adalah seorang perempuan dan berstatus sebagai narapidana, memiliki gangguan fobia spesifik pada telur asin. Asesmen yang digunakan pada subjek adalah wawancara, observasi dan tes psikologi (SSCT). Hasil asesmen menunjukkan bahwa subjek memang memiliki tendensi ketakutan yang berlebihan, terlihat dari skor SSCT aspek sikap terhadap ketakutan yang lebih tinggi dari aspek lainnya. Dampaknya, selain subjek merasa was-was ketika berada satu kamar dengan temannya di Lapas yang suka dengan telur asin, subjek juga sering bereaksi kaget bahkan ingin menjauh ketika ada orang lain yang mengatakan telur asin. Intervensi yang diberikan adalah terapi disensitisasi sistematis dengan 7 sesi. Tujuan intervensi ini adalah untuk menurunkan ketakutan subjek terhadap objek telur asin. Hasil dari intervensi menunjukkan bahwa terjadi penurunan skor ketakutan.

Kata kunci: Fobia, disensitisasi sistematis, intervensi
\end{abstract}

\section{Latar Belakang}

Fobia spesifik adalah salah satu gangguan psikologis yang paling umum terjadi dengan persentase kejadian sekitar 7-11\% dari populasi umum (APA, 2013). Fobia spesifik cenderung berlangsung terus-menerus selama bertahun-tahun atau selama beberapa dekade kecuali bila ditangani dengan baik. Biasanya perempuan mempunyai kemungkinan dua kali lebih besar dibandingkan laki-laki untuk mengalami fobia spesifik. Individu yang mengalami fobia spesifik dapat menimbulkan kondisi stress yang besar saat berhadapan atau harus melakukan sesuatu yang berkaitan dengan stimulus fobianya. Misalnya, seseorang dengan fobia anjing dapat membuat dirinya menjadi cemas dan berteriak-teriak dijalan ketika bertemu dengan anjing, 
seseorang dengan fobia lift tidak berani untuk menaiki lift dan mengharuskan dia untuk menaiki tangga bahkan untuk ke lantai 10 sekalipun dan sebagainya (Nevid, Rathus \& Greene, 2005). Ada banyak faktor yang dapat membuat individu mengalami fobia spesifik. Individu yang mempunyai kecenderungan mengalami fobia umumnya dipengaruhi oleh 2 faktor, yaitu faktor internal, seperti kemampuan otak menilai suatu peristiwa ataupun perasaan individu terhadap sesuatu. Kedua, faktor eksternal seperti hewan, tumbuhan dan lingkungan turut andil dapat membuat seseorang menjadi fobia (Nielsen, 2005).

Halgin dan Whitbourne (2009) mengungkapkan bahwa fobia spesifik adalah ketakutan irasional dan menetap pada objek khusus, aktivitas dan situasi yang menyebabkan respon kecemasan secara tiba-tiba, menyebabkan gangguan signifikan dalam performa, dan menghasilkan perilaku menghindar. Dalam jangka panjang, jika pengidap gangguan fobia spesifik melakukan perilaku menghindar secara terus-menerus dari objek/situasi yang ditakuti maka akan menyebabkan hubungan sosial dan pekerjaan menjadi terganggu (Witthauer et al., 2016). Selain itu, ketakutan ataupun kecemasan yang dialami oleh pengidap fobia dapat mengganggu keadaan fisik dan psikis. Secara fisik, jari-jari tangan akan menjadi dingin, detak jantung makin cepat, berkeringat dingin, kepala pusing, nafsu makan berkurang, tidur tidak nyenyak, dan sesak nafas. Sedangkan secara psikis, yaitu ketakutan, merasa akan ditimpa bahaya, tidak dapat memusatkan perhatian, tidak tenteram dan ingin lari dari kenyataan (Sundari, 2005). Apabila gangguan fobia tidak mendapat penanganan yang tepat, maka akan memunculkan konsekuensi negatif terhadap dirinya. Misal, merasa ketakutan berkepanjangan. (Marcaurelle, Belanger \& Marchand, 2003).

Permasalahan mengenai fobia spesifik yang dikemukakan diatas terjadi pada subjek, seorang perempuan dan berumur 17 tahun dengan status sebagai narapidana anak. Berdasarkan hasil asesmen, subjek mengeluhkan sering merasa kaget ketika mendengar kata telur asin, gelisah dan tidak tenang jika ada orang yang sedang membicarakan, memegang atau membawa telur asin. Bahkan, ketika dalam waktu yang relatif lama subjek mengetahui hal tersebut, maka ia akan merasa mual dan muntah. Hal tersebut menjadi penting untuk diberikan intervensi psikologi karena teman sekamar subjek menyukai telur asin sehingga ia sering beli telur asin di Warung Lapas ataupun mendapat kiriman dari orang tuanya. Selain itu, subjek pernah memiliki pengalaman muntah di kamarnya yang membuat kamar tersebut menjadi sangat kotor. Kejadian ini membuat subjek merasa tidak enak dengan teman sekamarnya dan tidak ingin lagi mengulangi hal tersebut.

Berdasarkan permasalahan di atas, maka subjek akan diberikan intervensi psikologi berupa terapi disensitisasi sistematis. Dalam kajian meta-analisis, ada banyak terapi perilaku, seperti in vivo exposure, imaginal exposure, flooding therapy, dan virtual reality and computer assisted exposure (Wolitzky-Taylor et al., 2008). Namun, terapi disensitisasi sistematis di pilih karena paling cocok dengan karakter subjek dan situasi tempat tinggal subjek. Alasannya adalah karena subjek tinggal di Lapas, sehingga terapis memilih jenis terapi dengan prosedur yang bertahap dalam menghadapi objek/situasi ketakutannya.

Terapi desensitisasi sistematis adalah jenis terapi yang menghadapkan subjek pada situasi yang memunculkan ketakutannya, namun situasi tersebut dikemas dalam situasi yang terkontrol dan aman bagi subjek. Terapi ini merupakan salah satu terapi penanganan rasa takut yang cukup efektif. Di dalam desensitisasi sistematis, individu akan membayangkan secara bertahap situasi yang memunculkan ketakutan kemudian melakukan perilaku yang melawan ketakutan misalnya dengan relaksasi. Diharapkan individu secara sistematis menjadi kurang sensitif (desensitif) terhadap situasi yang menimbulkan ketakutan ataupun kecemasan (Spieglerd \& Guevremont, 2003). Terapi desensitisasi sistematis merupakan terapi perilaku yang pertama kali digunakan secara luas untuk menangani fobia (Wolpe, 1958). Bukti-bukti dan eksperimen 
mengindikasikan bahwa teknik ini efektif untuk menghapuskan atau minimal mengurangi fobia (Davison, 2006).

\section{Metode Asesmen}

Ada tiga metode yang digunakan di dalam penelitian ini. Pertama, wawancara klinis dengan mengumpulkan informasi (data utama) yang mendalam terkait dengan subjek guna menunjang dalam melakukan penegakan diagnosa dari permasalahan subjek. Wawancara dilakukan kepada subjek secara langsung (Autoanamensa) serta kepada orang-orang disekitar (Alloanamnesa), seperti pegawai Lapas dan teman sekamar subjek.Kedua, observasi yang merupakan satu kesatuan yang tidak bisa terpisahkan dengan wawancara. Observasi bertujuan untuk menyelaraskan data yang didapat dari hasil wawancara. Secara konkret, observasi dilakukan secara tidak terstruktur, berupa pengamatan bahasa tubuh dan ekspresi ketika proses wawancara berlangsung. Dalam penelitian ini, observasi dilakukan ketika subjek mengikuti kegiatan senam pagi dan pondok pesantren.Ketiga, menggunakan alat tes psikologi SSCT (Sack Sentence Completion Test), bertujuan untuk mengungkap dinamika kepribadian subjek dalam hubungan interpersonal. Ruang lingkupnya adalah hubungan dengan keluarga, sikap dan hubungan terhadap lawan jenis, hubungan dengan sesama manusia di lingkungan sosial serta konsep diri.

\section{Presentasi Kasus}

Subjek merupakan perempuan yang berusia 17 tahun dan sedang menjalani sisa masa pidana akibat kasus penipuan dan pencurian. Subjek mengeluhkan sering merasa kaget ketika mendengar kata telur asin, gelisah dan tidak tenang jika ada orang yang sedang membicarakan, memegang atau membawa telur asin. Bahkan, ketika dalam waktu yang relatif lama subjek mengetahui hal tersebut, maka ia akan merasa mual dan muntah. Hal tersebut akan bertambah menjadi parah apabila subjek berhadapan secara langsung dengan objek telur asin. Akibatnya, perilaku yang biasanya ia lakukan adalah menghindari objek telur asin tersebut.

Saat kecil hingga kelas 3 SD, subjek sebenarnya tidak takut dengan telur asin, karena ayah subjek menyukai telur asin sehingga subjek sering melihat dan memegang telur asin. Akan tetapi, ketika kelas 4 SD subjek pernah mengalami sakit demam dan ketika itu mendapatkan hidangan makanan soto dengan telur asin oleh ayahnya. Setelah subjek makan telur asin yang ada didalam soto tersebut, subjek merasa tenggorokannya menjadi tidak nyaman dan mual. Akhirnya, subjek muntah dan diwaktu yang bersamaan badannya menjadi lemas. Beberapa hari setelahnya, subjek ke dokter bersama ayahnya karena demam subjek bertambah parah. Akan tetapi, informasi dari dokter tidak ditemukan permasalahan yang berkaitan dengan telur asin. Hal ini juga sesuai dengan riwayat keluarga subjek yang tidak ada masalah ataupun alergi dengan telur asin, bahkan ayah subjek menyukai telur asin.

Sejak saat itu subjek mulai takut dengan telur asin. Ketika subjek mendengar telur asin, maka ia teringat dengan pengalamannya waktu dulu muntah ketika makan telur asin hingga sakit demam yang bertambah. Asosiasi tentang pengalaman muntah tersebut semakin nyata di pikiran subjek jika ia membayangkan, melihat secara langsung apalagi mencium bau telur asin. Menurut subjek, yang paling membuat tidak nyaman dari telur asin adalah baunya. Hal tersebut membuat subjek sering diledek oleh teman-temannya dengan diberikan telur asin, namun reaksi subjek adalah menghindar dan tidak mau mendekati temannya tersebut.

Berdasarkan hasil asesmen ditemukan bahwa subjek memang memiliki tendensi untuk takut. Ketika dilapas subjek pernah mendapat tugas dari tamping (tahanan pendamping) untuk membawakan paket kiriman yang dibungkus plastik hitam kepada teman kamarnya. Kemudian subjek menuruti instruksi tersebut dan memberikan paket kiriman kepada teman kamarnya. Namun, ketika makan saat sore hari menjelang malam, temannya tersebut memberitahukan 
kepada subjek bahwa ternyata isi plastik tersebut telur asin dan temannya ingin memberikan telur asin kepada subjek sebagai lauk makan. Seketika itu juga, subjek langsung menolak dan menghindari temannya tersebut. Namun, temannya tersebut tetap memberikan telur asin kepada subjek yang membuat subjek mual dan akhirnya muntah. Kamar subjek menjadi penuh dengan kotoran dan bau yang membuat teman kamarnya menjadi risih dan menggerutu. Sejak saat itu, subjek semakin merasa tidak nyaman dengan rasa takutnya terhadap telur asin tersebut karena khawatir jika kedepannya pengalaman muntah ini akan terjadi lagi. Meskipun teman-teman sekamarnya mengetahui subjek takut dengan telur asin, namun terkadang mereka suka jahil dan menggoda subjek dengan mengatakan kata "telur asin". Akibatnya, subjek merasa ingin sekali sedikit lebih berani dengan telur asin agar tidak menjadi bahan candaan oleh teman-temannya.

\section{Diagnosis dan Prognosis}

Berdasarkan uraian kasus diatas, hasil asesmen dan rujukan yang ada di Diagnostic and Statistical Manual of Mental Disorder Fifth Edition (DSM-V), maka dapat ditegakan diagnosis bahwa subjek mengalami gangguan fobia spesifik (fobia telur asin). Terapis memperkirakan keberhasilan subjek dalam melakukan intervensi sebagai prognosis berada pada kategori positif/baik.

\section{Intervensi}

Metode intervensi yang gunakan pada kasus ini adalah terapi desensitisasi sistematis. Menurut Wolpe (1969), terapi desensitisasi sistematis adalah sebuah terapi yang efektif dalam menurunkan rasa takut ataupun cemas yang mengganggu. Prosesnya dilakukan dengan cara relaksasi terlebih dahulu. Kemudian, dihadirkan situasi-situasi yang menimbulkan perasaan takut mulai dari level yang terendah atau biasanya berupa imajinasi terlebih dahulu. Ketika perasaan takut muncul saat proses berlangsung, maka peserta akan diminta berhenti membayangkan situasi tersebut dan diminta untuk melakukan relaksasi terlebih dahulu. Diharapkan dengan menghadirkan kondisi-kondisi yang menimbulkan rasa takut secara berkelanjutan, maka level ketakutan akan melemah secara bertahap, hingga akhirnya subjek tidak lagi merasakan takut ataupun cemas terhadap stimulus pemicu. Terapi desensitisasi sistematis sering digunakan untuk mengurangi perilaku maladaptif akibat ketakutan ataupun kecemasan berlebih yang dipelajari melalui conditioning, seperti: fobia, ataupun juga bisa pada trauma. Terapi desensitisasi sistematis dapat membantu individu untuk melemahkan atau mengurangi perilaku maladaptifnya (Firosad, Nirwana \& Syahniar, 2016).

Adapun tujuan dari terapi desensitisasi sistematis pada kasus ini adalah untuk membantu subjek dalam menurunkan ketakutan terhadap telur asin. Diharapkan melalui terapi ini subjek pada akhirnya dapat mengubah perilaku menghindar/maladaptif ketika dihadapkan pada hal-hal yang menimbulkan ketakutan terhadap telur asin menjadi perilaku yang lebih adaptif. Hal ini berlaku, baik ketika mendengar orang lain mengatakan kata "telur asin", melihat gambar telur asin, menonton video tentang telur asin, maupun melihat dan memegang telur asin secara langsung. Terapi desensitisasi sistematis yang telah dilakukan didesain sebanyak 7 sesi:

Sesi 1: Identifikasi masalah dan menetapkan fokus masalah. Diskusi bersama subjek mengenai beragam permasalahan yang dialami selama di Lapas, kemudian menentukan fokus pada satu masalah yang akan diselesaikan. Selain itu, alasan mengapa hanya satu fokus masalah yang dipilih untuk diselesaikan juga penting untuk dibahas. Tujuannya adalah agar kesadaran subjek akan pentingnya dilakukan sesi intervensi semakin meningkat.

Sesi 2: Membangun komitmen, kontrak kerja dan pengenalan terapi. Terapis mengajak subjek untuk membangun motivasi yang tinggi untuk bisa mengikuti sesi intervensi hingga 
selesai. Kemudian, menjelaskan gambaran terapi yang akan dilaksanakan. Terakhir, pengisian informed consent oleh subjek.

Sesi 3: Psikoedukasi tentang telur asin. Terapis menjelaskan kepada subjek tentang perbedaan telur asin dengan telur-telur lainnya, proses pembuatan telur asin, komposisi yang ada pada telur asin serta manfaat telur asin untuk kesehatan tubuh. Tentunya penjelasan tersebut diberikan dengan singkat, padat, jelas serta menggunakan bahasa-bahasa ringan dan mudah dimengerti oleh subjek. Selain itu, agar proses penjelasan berjalan lebih optimal, terapis memberikan kesempatan seluas-luasnya kepada subjek untuk bertanya sehingga diskusi yang terjadi dilakukan secara dua arah.

Sesi 4: Relaksasi pernafasan. Relaksasi pernafasan dipilih karena jenis relaksasi ini adalah relaksasi yang paling mudah untuk dilakukan, mengingat usia subjek masih terbilang muda sehingga membutuhkan sesuatu yang tidak terlalu rumit. Pada awal sesi, terapis memberikan sesi pernafasan terlebih dahulu kepada subjek sebagai bentuk contoh agar subjek dapat melakukannya secara mandiri. Kemudian terapis meminta feedback kepada subjek berupa kondisi sebelum dan sesudah diberikan relaksasi serta menanyakan apakah subjek sudah bisa mempraktekkannya secara mandiri.

Sesi 5: Identifikasi hierarki ketakutan. Pada sesi ini subjek dibantu dengan terapis menemukan hierarki ketakutan dari situasi ketakutan yang paling rendah hingga paling tinggi. Terapis diharapkan dapat membantu subjek untuk menemukan gambaran ketakutan secara jelas dan konkret, kemudian menuliskannya disebuah kertas.

Sesi 6: Terapi desensitisasi sistematis. Pada sesi ini, subjek dihadapkan kepada situasi yang menimbulkan ketakutan secara bertahap. Sebelumnya, semua perlengkapan yang dibutuhkan untuk menjalani sesi ini sudah dipersiapkan oleh terapis. Selama proses ini berlangsung, terapis juga menanyakan pertanyaan scalling tentang ketakutannya disetiap sebelum dan sesudah melewati setiap hierarki ketakutan. Jika berhasil, terapis memberikan penguatan positif berupa pujian dan motivasi kepada subjek. Selain itu, sebelum subjek menghadapi ketakutan disetiap level, terapis juga kembali mengingatkan kepada subjek untuk melakukan relaksasi pernafasan agar perilaku takut dapat dihambat.

Sesi 7: Evaluasi dan terminasi. Terapis mengulas balik secara singkat proses terapi yang telah dilakukan. Kemudian, melakukan evaluasi terhadap makna baru yang telah di tanamkan, mengevaluasi pengubahan sikap yang telah di aplikasikan, dan menyimpulkan hal-hal yang telah dipelajari subjek selama proses intervensi. Selain itu, terapis kembali memotivasi subjek agar cemas yang dirasakan berkurang hingga siap dengan segala macam keadaan ketika bebas pidana. Pada sesi ini, subjek mendengarkan arahan terapis dengan baik.

\section{Hasil dan Pembahasan}

\section{Hasil}

Tahapan awal dalam intervensi adalah menentukan fokus atau target yang akan di capai, sesuai dengan kebutuhan subjek. Berdasarkan keluhan subjek berupa ketakutan berlebihan terhadap telur asin. Hal tersebut menjadi penting untuk dijadikan target intervensi karena salah satu teman kamar subjek di lapas menyukai telur asin. Subjek juga pernah muntah di dalam kamar sehingga membuat kamar tersebut kotor dan teman-teman satu kamarnya menjadi risih dan menggerutu. Selain itu, dengan mempertimbangkan waktu magang terapis yang terbatas selama di Lapas. Oleh karena itu, target realistis yang disepakati antara subjek dan terapis adalah menurunkan ketakutan subjek terhadap objek telur asin.

Sebelum masuk sesi terapi desensitisasi sistematis, subjek diberikan psikoedukasi terlebih dahulu tentang telur asin. Pada sesi ini, subjek mendapatkan banyak informasi yang selama ini 
tidak di ketahuinya mengenai telur asin. Informasi tersebut diberikan melalui sebuah modul yang menjelaskan mengenai perbedaan telur asin dengan telur-telur lainnya, proses pembuatan telur asin, komposisi yang ada pada telur asin serta manfaat telur asin untuk kesehatan tubuh. Ketika dijelaskan poin mengenai manfaat telur asin, dari ekspresi wajahnya subjek mengangguk dan terlihat menjadi lebih santai. Melalui sesi ini, subjek semakin menyadari bahwa subjek memiliki pikiran yang tidak rasional terhadap objek telur asin. Subjek menyadari bahwa sebenarnya telur asin membawa manfaat bagi dirinya dan secara umum mampu mengembangkan pikirannya menjadi lebih rasional. Sesi ini menjadi bekal bagi subjek untuk menjalani sesi intervensi selanjutnya.

Sesi terapi disensitisasi sistematis diberikan selama 5 hari. Hari ke-1, subjek menjalani dua hierarki ketakutan yaitu mendengarkan dan mengucapkan serta membayangkan telur asin. Pada awalnya, skor ketakutan mendengarkan dan mengucapkan kata telur asin berada pada angka 4 sedangkan membayangkan berada pada angka 5. Namun, ketika terapis menyarankan subjek untuk relaksasi pernafasan terlebih dahulu sebelum mendengarkan dan mengatakan kata "telur asin", reaksi subjek menjadi lebih tenang dan skor turun menjadi angka 1. Skor ketakutan membayangkan telur asin turun menjadi angka 2. Hal ini disebabkan karena adanya sesi psikoedukasi mengenai telur asin yang sudah diberikan sebelumnya sehingga membuat subjek menjadi sudah terbiasa dengan kata telur asin. Hari ke-2, terapis membawakan foto telur asin. Skor awal berada pada angka 7. Namun, terapis menyarankan subjek untuk relaksasi pernafasan terlebih dahulu dan memberikan motivasi kepada subjek. Akhirnya, subjek mulai berani melihat bahkan mengamati foto telur asin tersebut. Setelahnya di ukur skor ketakutan turun menjadi angka 4. Hari ke-3 sampai dengan ke-5, prosedur yang dilakukan sama seperti hari-hari sebelumnya. Hanya saja di hari ke-3, subjek menonton video telur asin melalui laptop yang sudah disediakan terapis. Hari ke-4 dan ke-5, terapis membawa telur asin secara langsung untuk di jadikan media intervensi. Hari ke-4 subjek melihat secara langsung telur asin tanpa harus memegang, sedangkan hari ke-5 subjek melihat, memegang telur asin secara langsung, mendekatkan ke hidung dan mencium bau telur asin.

Dari setiap hierarki ketakutan yang dilakukan di setiap harinya, terdapat perbedaan skor ketakutan antara sebelum di berikan intervensi dan sesudahnya. Setiap hierarki ketakutan yang dilakukan oleh subjek mengalami penurunan skor. Lebih jelasnya lihat Gambar 1

Setiap kali subjek berhasil menurunkan skor ketakutan, maka terapis memberikan penguatan berupa pujian dan motivasi kepada subjek. Selain itu, agar lebih memotivasi subjek, pada hari terakhir terapis memberikan cokelat kepada subjek jika berhasil menurunkan angka ketakutan sebagai bentuk penguatan. Alasan dipilihnya cokelat sebagai bahan untuk penguatan karena subjek sangat menyukai cokelat, akan tetapi tidak bisa beli karena di kantin lapas tidak tersedia. Pada tahap evaluasi dan terminasi, terapis menanyakan kepada subjek tentang perubahan secara keseluruhan yang dirasakan dari awal sesi intervensi hingga akhir.

\section{Pembahasan}

Beragam penelitian telah menunjukkan efektivitas dari terapi disensitisasi sistematis terhadap gangguan fobia. Seperti penelitian yang dilakukan oleh Ambarita (2016), terapi disensitisasi sistematis dapat menurunkan rasa cemas pada seorang penderita fobia suntikan dengan penurunan tingkatan rasa cemas dari 100 SUD menjadi 30 SUD. Meskipun terapi disensitisasi sistematis dilakukan secara mandiri di rumah. Hal ini disebabkan karena selama proses terapi disensitisasi sistematis dapat timbul insight yang menyadarkan penderita tentang pemikiran yang irasional. Penelitian Firosad, Nirwana dan Syahniar (2016) menghasilkan data bahwa terapi disensitisasi sistematis efektif mengurangi fobia spesifik pada 8 mahasiswa yang tergabung kedalam kelompok eksperimen. Kombinasi antara terapi disensitisasi sistematis dengan terapi yang lain juga menunjukkan hasil yang sama. Terapi disensitisasi sistematis 


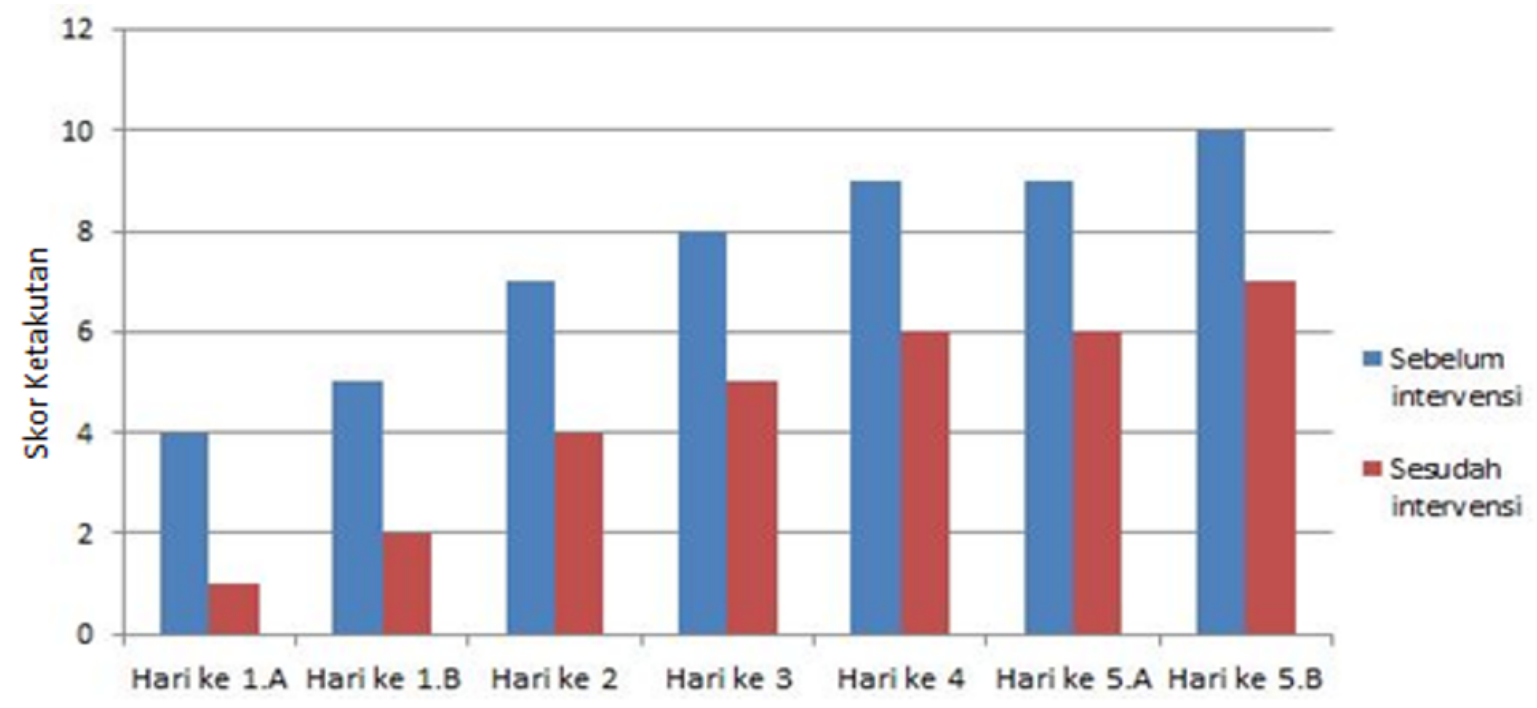

Gambar 1. Penurunan skor ketakutan.

dengan dzikir tasbih juga dapat menurunkan simtom kecemasan pada gangguan fobia spesifik (Azmarina, 2015). Selanjutnya, penelitian Nanik dan Gunawinata (2011) memperlihatkan bahwa kombinasi bibliotherapy, terapi kognitif, relaksasi dan terapi disensitisasi sistematis menghasilkan perubahan efektif pada penderita fobia lift, padahal latihan belum sampai menggunakan lift.

Dari beragam penelitian yang telah disebutkan diatas, maka terapis merasa penting untuk menambahkan psikoedukasi diawal tentang telur asin kepada subjek. Hal ini dilakukan dengan tujuan memperkuat intervensi yang diberikan. Pada dasarnya, terapi disensitisasi sistematis bertujuan mengajarkan subjek untuk memberikan respon yang tidak konsisten dengan kecemasan yang dialami. Terapi ini mengajarkan subjek untuk santai dan menghubungkan keadaan santai itu dengan membayangkan pengalaman yang mencemaskan dan menakutkan. Situasi yang dihadirkan disusun secara sistematis dari yang kurang mencemaskan hingga yang paling mencemaskan (Willis, 2004). Terapi disensitisasi sistematis merupakan salah satu teknik perubahan perilaku yang didasari oleh teori atau pendekatan behavioral klasikal.

Pendekatan behavioral memandang manusia atau kepribadian manusia pada hakikatnya adalah perilaku yang dibentuk berdasarkan hasil pengalaman dari interaksi individu dengan lingkungannya. Perhatian behavioral adalah pada perilaku yang nampak, sehingga terapi tingkah laku mendasarkan diri pada penerapan teknik dan prosedur yang berakar pada teori belajar yakni menerapkan prinsip-prinsip belajar secara sistematis dalam proses perubahan perilaku menuju kearah yang lebih adaptif. Latar belakang dan sejarah terapi disensitisasi sistematis melihat bahwa rasa takut dipelajari lewat pengkondisian, demikian juga sebaliknya rasa takut dapat dihilangkan lewat pusat pengkondisiannya. Terapi disensitisasi sistematis dikembangkan dalam tradisi behavioristik pada awal tahun 1950 oleh Joseph Wolpe. Prosedur treatment ini dilandasi oleh prinsip belajar counterconditioning, yaitu respon yang tidak diinginkan digantikan dengan tingkah laku yang diinginkan sebagai hasil latihan yang berulang-ulang. Terapi disensitisasi sistematis ini sangat efektif untuk menghilangkan rasa takut atau fobia spesifik (Corey, 2007; Martin \& Pear, 2007).

\section{Simpulan}

Terapi disensitisasi sistematis dapat membantu menurunkan ketakutan orang dengan gangguan fobia spesifik. Penurunan skor mengenai ketakutan subjek terhadap telur asin dapat terjadi karena tahapan terapi disensitisasi sistematis dari awal hingga evaluasi. Terapi yang diberikan 
mungkin belum mampu menurunkan ketakutan subjek sepenuhnya, disebabkan karena waktu magang di lapas yang terbatas. Namun, skor mengenai ketakutan subjek terhadap telur asin akan terus turun jika subjek mau secara konsisten melakukan tahapan-tahapan tersebut secara mandiri sehingga dalam jangka panjang subjek sudah tidak terganggu sepenuhnya dengan telur asin ketika beraktivitas sehari-hari.

\section{Referensi}

Ambarita, T. F. A. (2016). Terapi desensitisasi sistematik dalam menurunkan tingkat kecemasan pada fobia jarum suntik. Majalah Ilmiah Methoda, 6(1). 20-28.

American Psychiatric Association. (2013). Diagnostic and statistical manual of mental disorder (5th. ed.). United States of America: America Psychiatric Publishing.

Azmarina, R. (2015). Desensitisasi sistematik dengan dzikir tasbih untuk menurunkan simtom kecemasan pada gangguan fobia spesifik. Humanitas: Jurnal Psikologi Indonesia, 12(2)..

Corey, G. (2007). Teori dan praktek konseling dan psikoterapi diterjemahkan oleh E, Koswara. PT. Refika Aditama: Bandung.

Davison, G.C. (2006). Psikologi abnormal. Jakarta: Rajawali pers.

Firosad, A. M., Nirwana, H., \& Syahniar, S. (2016). Teknik desensitisasi sistematik untuk mengurangi fobia mahasiswa. Konselor, 5(2), 100-107.

Halgin, R. P., \& Whitbourne, S. K. (2010). Psikologi abnormal: Perspektif klinis pada gangguan psikologis. Jakarta: Salemba Humanika.

Marcaurelle, R., Bélanger, C., \& Marchand, A. (2003). Marital relationship and the treatment of panic disorder with agoraphobia: A critical review. Clinical Psychology Review, 23(2)., 247-276.

Martin, G. \& Pear, J. (2007). Behavior modification: What it is and how to do it (8th. ed.). USA: Pearson Prentice Hall.

Nanik, N., \& Gunawinata, V. A. R. (2011). Terapi perilaku untuk fobia lift. Jurnal Ilmiah Psikologi, 5(2), 215-224.

Nevid, J.S., Rathus, S.A. \& Greene, B. (2005). Psikologi abnormal, edisi kelima, Jilid 2. Jakarta: Penerbit Erlangga.

Nielsen, C. (2005). "Therapy for a new age”. Australian Counselling Association Journal, 5 (2): 38-42.

Sundari, S. (2005). Kesehatan mental dalam kehidupan. Jakarta: Rineka Cipta.

Spiegler, M.D., \& Guevremont, D.C. (2003) Contemporary behavior therapy. Thomson Learning: New York.

Willis, S. (2004). Konseling Individual: Teori dan praktek. Bandung: Alfabeta.

Witthauer, C., Ajdacic-Gross, V., Meyer, A. H., Vollenweider, P., Waeber, G., Preisig, M., \& Lieb, R. (2016). Associations of specific phobia and its subtypes with physical diseases: An adult community study. BMC Psychiatry, 16(1)., 155.

Wolitzky-Taylor, K. B., Horowitz, J. D., Powers, M. B., \& Telch, M. J. (2008). Psychological approaches in the treatment of specific phobias: A meta-analysis. Clinical Psychology Review, 28(6)., 1021-1037.

Wolpe, J. (1961). The systematic desensitization treatment of neuroses. Journal of Nervous and Mental Diseases, 132., 180-203.

Wolpe, J. (1969). The practice of behavior therapy. New York: Pergamon Press. 